\section{Generic drugs in Brazil: known by many, used by few}

\author{
Medicamentos genéricos no Brasil: \\ conhecidos por muitos, usados por poucos
}

\author{
1 Programa de Pós-graduação \\ em Epidemiologia, \\ Universidade Federal \\ de Pelotas, Pelotas, Brasil. \\ Correspondência \\ A. D. Bertoldi \\ Programa de Pós-graduação \\ em Epidemiologia, Faculdade \\ de Medicina, Universidade \\ Federal de Pelotas. \\ Av. Duque de Caxias 250, \\ Pelotas, RS 96030-002, Brasil. \\ andreabertoldi@terra.com.br
}

\section{Abstract}

This study evaluated knowledge and use of generic drugs in a population-based sample of adults from a southern Brazilian city. The outcomes were: the proportion of generics in total medicines used; theoretical and practical knowledge about generics; and strategies used to buy medicines on medical prescriptions. The recall period for drug utilization was 15 days. The proportion of generics in total medicines was $3.9 \%$. While $86.0 \%$ knew that generics cost less and $70.0 \%$ that the quality is similar to brand name medicines, only 57.0\% knew any packaging characteristics that distinguish generics from other medicines. The highest proportion of generic drug utilization was in the antimicrobial pharmacological group. A brand name medicine (with a brand similar to the generic name) was mistakenly classified as a generic through photos by $48.0 \%$ of the interviewees. Among subjects who bought medicines in the 15-day period, $18.9 \%$ reported buying a generic, but this result should be interpreted with caution, because the population frequently fails to differentiate between generics and other medicines.

Pharmacoepidemiology; Drug Costs; Drug Utilization; Generic Drugs; Health Policy
Andréa D. Bertoldi 1

Aluísio J. D. Barros 1

Pedro C. Hallal 1

\section{Introduction}

Drug utilization is affected not only by health conditions, but also by anthropological, cultural, and economic variables 1,2. In Brazil, medicines represent $37.0 \%$ of household expenditure on health 3 . Availability of high-quality drugs at affordable prices is thus a public health priority, particularly for the poor, who constitute the majority in most developing countries.

The World Health Organization (WHO) encourages policies to promote the use of generic drugs, with lower prices than traditional brand name medicines and quality equivalent to that of reference drugs, as confirmed by bioequivalence and bioavailability tests.

Until 1999, industrialized medicines in Brazil could be classified as brand name drugs (mostly from multinational companies) or so-called similar drugs (mostly produced by local laboratories and sold by the substance name, without a brand name). At that time, the so-called similar drugs were much cheaper than brand name medicines. In 1999, a generic drug policy was implemented in Brazil 4, and one year later all industrialized medicines except registered generic drugs were required to be sold under a brand name 5 .

Presently, medicines in the Brazilian retail market can be classified in one of the following groups:

- Formulated medicines: prepared on order at pharmacies, following a customized medical 
prescription and identified by the substance names. Prices are generally lower than those of equivalent industrialized medicines, including generics.

- Industrialized medicines: medicines manufactured by the pharmaceutical industry and sold pre-packaged. These can be classified in the following four subgroups: (a) Generics: commercialized by substance name, without a brand name. This is the only group that can be legally used to replace a reference drug. Registered generics are clearly identified by a yellow stripe, with a capital "G", and the Generic Drugs Act number displayed on the outside of the package. (b) Brand name medicines: original brand name drugs, generally more expensive than generic drugs, and not interchangeable with other medicines. (c) Brand name similar medicines: are basically brand name medicines, but differentiated from the previous group because they are the former similar medicines sold under substance names. They are now sold under retail brand names, but remain cheaper than the original brand name medicines and are usually also cheaper than generics. This group is referred to in this paper as similar medicines. They are also not interchangeable with reference drugs and until 2003 did not offer the same quality guarantee as the generics. (d) Natural and homeopathic medicines: placed in a separate group, since they are based on homeopathic or natural substances rather than chemical products and have no generic equivalents.

In Brazil, there are three retail groups for medicines: "over the counter", sold freely without a medical prescription, "red label", sold against presentation of a medical prescription, and "black label", where the pharmacist keeps a copy of the prescription. In practice, sale of red label medicines is free, and consumers unreservedly choose replacements for their prescriptions, usually a cheaper alternative. It is also possible for similar medicines to be purchased inadvertently in the belief that they are generics.

This study was designed to: (a) estimate the proportion of generic drugs in the total of medicines used; (b) assess the population's knowledge of generic drug characteristics; and (c) study the most common criteria used for purchasing medicines.

\section{Methods}

A population-based cross-sectional study was conducted in the first semester of 2002 in Pelotas, southern Brazil. A representative household sample was selected following a multiplestage protocol. Census tracts defined by the Instituto Brasileiro de Geografia e Estatística (IBGE) were the primary sample units, while households in each sampled tract were the secondary sample units. All residents aged 20 years or older were eligible, except those with severe mental impairment.

The final sample $(n=3,182)$ allowed estimating a $4.0 \%$ prevalence of generic drug use with an error of 0.8 percentage points and $95.0 \%$ confidence interval. The sample size was sufficient to identify potential associations between generic drug use and independent variables using the following parameters: $95 \% \mathrm{CI}, 80.0 \%$ power, $25.0 \%$ exposure prevalence, and a minimum relative risk of 2.0 .

The study explored three outcomes: (a) the proportion of generics in total medicines used in the 15 days prior to the interview; (b) theoretical and practical knowledge about generics; and (c) strategies for choosing medicines when purchasing on medical prescriptions.

Interviewees were asked about the utilization of any medicine in the previous 15 days and requested to show the packaging and prescription. Drugs for which the packaging was available were classified as generic, brand name, similar, formulated, and natural or homeopathic medicines.

To be classified as a generic, the package had to display the official logo or legislation number of generic drugs printed under the drug name. Brand name drugs were differentiated from similar drugs by the pharmaceutical laboratory. Formulated medicines were identified by the package bearing the name of a local pharmacy. In Brazil, except for formulated preparations, drugs can only be dispensed in their original packaging, thus in pre-defined doses and quantities. All drugs were classified into pharmacological groups using the Brazilian National List of Essential Drugs (RENAME) 6.

Knowledge about generics was verified with the following questions: (a) Does the generic drug cost more, the same, or less than the brand name drug? (b) Is the quality of generic drugs better, the same, or worse than that of brand name drugs? (c) What does the generic drug packaging contain that differentiates it from other drugs? 
The practical ability to recognize a generic was tested using pictures reproducing packages from selected drugs. Initially, a brand name drug was shown to the interviewee. Next, a similar drug and generic for the first drug were shown. In both cases the person was asked whether the drug was a generic.

Strategies for choosing preparations when purchasing a medical prescription were investigated for the last purchase in the previous 15 days, or the habitual strategy for interviewees who had not purchased medicines during that period. Interviewees were asked whether they: (a) bought (or always buy) exactly the prescribed medicine; (b) replaced (usually replace) the prescribed drug with the corresponding generic; (c) replaced (usually replace) the prescribed drug with a formulated product; and (d) replaced (usually replace) the prescribed drug with a lower-priced alternative, regardless of whether it was a generic, formulated, or similar drug.

The independent variables were: gender, age, schooling, and economic status (Brazilian Economic Classification Criterion 7, an assetbased wealth index classifying individuals in five groups, from $A$, the wealthiest, to $E$, the poorest). Trained interviewers conducted the data collection, and field supervisors were responsible for quality control, which involved re-interviewing $10.0 \%$ of the total sample.

After calculating descriptive statistics, a crude analysis compared frequency of outcomes according to groups of independent variables. All analyses considered the sample clustering, using the commands "svy" from Stata 7.0. Two types of analysis were performed. The first used the number of individuals in the sample $(\mathrm{n}=$ 3,182 ) as the denominator, while the second used the number of drugs for which the packaging was shown $(n=3,305)$.

The study was approved by the Research Ethics Committee of the Faculdade de Medicina, Universidade Federal de Pelotas. Interviews were performed after informed consent.

\section{Results}

Among the 1,600 sampled households, 3,372 eligible individuals were found, of whom 3,182 agreed to answer the questionnaire (non-response rate: $5.6 \%$ ). Table 1 describes the sample according to demographic and socioeconomic variables. Individuals had used from 0 to 15 drugs in the previous 15 days, an average of 1.5 drugs per person. In total, 4,609 drugs were used (some were reported several times). Packaging from $72.7 \%(n=3,352)$ of the drugs was inspected, of which it was possible to classify $3,350: 51.2 \%$ were brand name drugs, $25.6 \%$ similar, $18.0 \%$ formulated, $3.9 \%$ generics, and $1.3 \%$ natural or homeopathic products (Table 2).

Using the 3,182 individuals as the denominator, the proportion of individuals who had used at least one generic drug in the previous 15 days was $3.6 \%$ (95\%CI: 3.0-4.3).

Table 2 shows the association between types of drugs and independent variables. Brand name drugs were used more by the younger, wealthier, and more educated. Similar products had an opposite distribution, preferred by middle-aged adults and the poorer and less educated. Generics were rarely used, and there was no difference in relation to the study variables. Formulated drugs were more used by the older, wealthier, and more educated. Natural and homeopathic products were uncommon in our sample. No gender differences were found for the different types of drugs.

Table 3 shows the frequency distribution of generics and other types of drugs in the most common pharmacological groups (only those with generics were included). The highest relative utilization of generics was among antimicrobials (15.3\%) and analgesic/anti-inflammatory drugs (5.6\%). Similar drugs showed higher frequencies in the same groups: $36.3 \%$ and $34.5 \%$, respectively. Brand name drugs were the most widely used in all pharmacological groups, with a higher relative share in drugs for the endocrine system.

Interviewees were knowledgeable about generics: $86.0 \%$ said that they cost less than brand name drugs; $70.0 \%$ believed that the quality of generics was equivalent to that of brand name drugs; $56.6 \%$ could identify some of the packaging characteristics that differentiate generics from other drugs. Correct answers were given to all three questions by $42.0 \%$ of interviewees.

Regarding the ability to correctly recognize a generic, $48.0 \%$ of the interviewees incorrectly classified a similar drug as a generic, while only $12.0 \%$ wrongly classified a generic as a similar drug. The percentage of erroneous classification of similar drugs as generics was significantly lower $(\mathrm{p}<0.01)$ among individuals who could mention at least one packaging characteristic of generics. However, $32.6 \%$ of these incorrectly classified a similar medicine as a generic.

Incorrect identification of similar drugs as generics did not differ between genders, but increased significantly with age and decreased with schooling and economic status (Table 4). Individuals who correctly identified a generic 
in the practical evaluation used generic drugs twice as often $(\mathrm{p}<0.01)$ as those who failed to do so ( $4.6 \%$ and $2.5 \%$, respectively).

The same trend was observed for individuals who mentioned at least one packaging characteristic differentiating generics from other drugs, but knowledge about price and quality of generics compared to brand name drugs was not associated with use of generics.

The proportion of individuals who had purchased drugs on prescription in the previous 15 days was $30.4 \%(n=964)$. The proportion of generics utilization was $7.7 \%$ for those who reported buying exactly the prescribed medicine, $10.6 \%$ for those who replaced the prescribed drug with a generic, and $4.1 \%$ for those who replaced the prescribed drug with a cheaper product, regardless of whether it was a generic, formulated, or similar drug $(\mathrm{p}<0.01)$. None of the individuals who replaced prescribed products with formulated drugs had used a generic during the 15 days prior to the interview.

Strategies for choosing drugs were markedly different between individuals who had purchased drugs in the previous 15 days and the others, who reported their normal habits for
Table 1

Sample description ( $n=3,182$ ) according to demographic and socioeconomic variables. Pelotas, Rio Grande do Sul, Brazil, 2002.

\begin{tabular}{lrr}
\hline Variables & $\mathbf{n}$ & $\%$ \\
\hline Gender & 1,374 & \\
Male & 1,808 & 43.2 \\
Female & & 56.8 \\
& & \\
Age (years) & 1,399 & 44.0 \\
20-39 & 1,200 & 37.7 \\
$40-59$ & 583 & 18.3 \\
$\geq 60$ & & \\
Economic status & & \\
A-B (wealthiest) & 747 & 23.6 \\
C & 1,270 & 40.0 \\
D-E & 1,153 & 36.4 \\
Schooling (years) & & \\
0-4 & & 27.7 \\
$5-8$ & 1,067 & 33.6 \\
$\geq 9$ & 1,231 & 38.7 \\
\hline
\end{tabular}

* Source: Associação Nacional de Empresas de Pesquisa ${ }^{7}$.

Types of medicines used ( $n=3,305)$ according to demographic and socioeconomic variables. Pelotas, Rio Garnde do Sul, Brazil, 2002.

\begin{tabular}{|c|c|c|c|c|c|}
\hline \multirow[t]{2}{*}{ Variables } & \multicolumn{5}{|c|}{ Proportion of each type of medicines used (\%) } \\
\hline & $\begin{array}{l}\text { Brand name } \\
\text { medicines }\end{array}$ & Similar medicines & Generic drugs & $\begin{array}{l}\text { Formulated } \\
\text { medicines }\end{array}$ & $\begin{array}{c}\text { Natural products/ } \\
\text { Homeopathic medicines }\end{array}$ \\
\hline Total & 51.2 & 25.6 & 3.9 & 18.0 & 1.3 \\
\hline Gender & $p=0.6^{*}$ & $p=0.4^{\star}$ & $p=1.0^{*}$ & $p=0.07^{\star}$ & $p=0.5^{\star}$ \\
\hline Male & 50.1 & 29.5 & 4.0 & 15.4 & 1.1 \\
\hline Female & 51.5 & 24.3 & 3.9 & 18.9 & 1.4 \\
\hline Age (years) & $p<0.001^{\star *}$ & $p<0.001^{\star *}$ & $p=0.5^{\star \star}$ & $p<0.001^{\star \star}$ & $p=0.2^{\star \star}$ \\
\hline $20-39$ & 60.8 & 24.1 & 3.4 & 9.8 & 1.9 \\
\hline $40-59$ & 48.4 & 27.1 & 4.1 & 19.4 & 1.1 \\
\hline$\geq 60$ & 48.0 & 25.2 & 4.2 & 21.5 & 1.2 \\
\hline Economic status ${ }^{\star \star \star}$ & $p=0.001 \star \star$ & $\mathrm{p}<0.001^{\star *}$ & $p=0.7^{\star \star}$ & $p<0.001 * \star$ & $p=0.004^{\star \star}$ \\
\hline A-B (wealthiest) & 55.4 & 14.4 & 4.2 & 23.7 & 2.3 \\
\hline $\mathrm{C}$ & 52.9 & 23.1 & 3.7 & 19.0 & 1.3 \\
\hline$D-E$ & 46.2 & 36.7 & 3.8 & 12.7 & 0.6 \\
\hline Schooling (years) & $p=0.04^{\star \star}$ & $p<0.001^{\star \star}$ & $p=0.4^{\star \star}$ & $p=0.01 * \star$ & $p=0.3^{\star \star}$ \\
\hline $0-4$ & 50.4 & 29.2 & 4.3 & 15.0 & 1.1 \\
\hline $5-8$ & 46.9 & 29.1 & 3.7 & 19.2 & 1.2 \\
\hline$\geq 9$ & 56.4 & 17.7 & 3.7 & 20.5 & 1.7 \\
\hline
\end{tabular}

* Wald test for heterogeneity;

$\star *$ Wald test for trend;

$\star \star \star$ Source: Associação Nacional de Empresas de Pesquisas 7. 
Absolute number $(\mathrm{N})$ and relative frequency $(\%)$ of drug utilization according to type $(\mathrm{n}=3,305)$ within the most commonly used pharmacological groups. Pelotas, Rio Grande do Sul, Brazil, 2002.

\begin{tabular}{|c|c|c|c|c|c|c|}
\hline \multirow[t]{2}{*}{ Pharmacological group* } & \multirow[b]{2}{*}{$N$} & \multirow[b]{2}{*}{$\begin{array}{l}\text { Brand name } \\
\text { medicines }\end{array}$} & \multicolumn{2}{|c|}{ Type of medicines (\%) } & \multirow[b]{2}{*}{$\begin{array}{l}\text { Formulated } \\
\text { medicines }\end{array}$} & \multirow[b]{2}{*}{$\begin{array}{c}\text { Natural products } \\
\text { homeopathic } \\
\text { medicines }\end{array}$} \\
\hline & & & $\begin{array}{l}\text { Similar } \\
\text { medicines }\end{array}$ & Generic drugs & & \\
\hline Cardiovascular system & 977 & 43.7 & 28.8 & 4.2 & 23.1 & 0.2 \\
\hline Analgesic and anti-inflammatory & 675 & 56.3 & 34.5 & 5.6 & 3.6 & 0.0 \\
\hline Endocrine system & 411 & 80.6 & 10.2 & 2.4 & 6.8 & 0.0 \\
\hline Central nervous system & 376 & 49.7 & 12.5 & 3.2 & 34.6 & 0.0 \\
\hline Digestive system & 237 & 41.7 & 30.4 & 1.7 & 24.1 & 2.1 \\
\hline Antimicrobials & 124 & 37.1 & 36.3 & 15.3 & 11.3 & 0.0 \\
\hline Respiratory system & 117 & 68.4 & 26.5 & 1.7 & 1.7 & 1.7 \\
\hline
\end{tabular}

* Only pharmacological groups that include generic drugs in Brazil. $\chi^{2}$ test: $p<0.001$.

Table 4

Misclassification of similar drugs as generics (using photos of selected product packages) according to demographic and socioeconomic variables. Pelotas, Rio Grande do Sul, Brazil, 2002.

\begin{tabular}{|c|c|c|}
\hline Variable* & $\begin{array}{l}\text { Percentage of } \\
\text { misclassification }\end{array}$ & $P$ value \\
\hline Gender & & $0.07 \star \star$ \\
\hline Male & 46.8 & \\
\hline Female & 49.5 & \\
\hline Age (years) & & $<0.001^{* * *}$ \\
\hline $20-39$ & 43.6 & \\
\hline $40-59$ & 48.9 & \\
\hline$\geq 60$ & 58.5 & \\
\hline Economic status \# & & $<0.001 * \star \star$ \\
\hline A-B (wealthiest) & 46.4 & \\
\hline C & 51.8 & \\
\hline$D-E$ & 59.4 & \\
\hline Schooling (years) & & $<0.001^{\star \star *}$ \\
\hline $0-4$ & 57.8 & \\
\hline $5-8$ & 50.2 & \\
\hline$\geq 9$ & 39.8 & \\
\hline
\end{tabular}

${ }^{\star} \mathrm{n}=3,182$

** Wald test for heterogeneity;

$\star \star *$ Wald test for trend

\# Source: Associação Nacional de Empresas de Pesquisas 7. purchasing pharmaceuticals (Figure 1). Among the 908 individuals who only replaced the prescribed product with a generic (or those who had done so on the last purchase), the percentage of generic drug use was $3.7 \%$, almost the same as in the entire sample (3.6\%).

\section{Discussion}

Generic drug utilization was low and not compatible with the reported drug purchasing strategies. The results indicated good population knowledge on price and quality of generics in comparison to brand name products. However, the theoretical and practical recognition of generics was inadequate. Nearly half of the individuals failed to mention at least one packaging characteristic that differentiates generics from other medicines. In addition, almost half mistakenly classified a similar drug as a generic.

To our knowledge, this is the first population-based study investigating the knowledge and utilization of generic drugs in Brazil. Most comparisons are with the National Survey on Consumers of Generic Drugs (http://www.anvisa.gov.br/hotsite/genericos/index.htm, accessed on 01/Jun/2004) conducted by the Ministry of Health and the Agência Nacional de Vigilância Sanitária (ANVISA) in 2001, with 2,220 consumers aged 16 to 74 years in 236 cities. The interviews took place at pharmacies just after individuals had purchased some medicine.

Generics were created to reduce family expenses with medicines and to increase compe- 
tition in an area dominated by multinational laboratories. As a result, generics have to be marketed at reduced prices in relation to brand name products. The $86.0 \%$ of individuals who knew that generics are cheaper than brand name drugs probably indicates that people associate the term "generic" with low price. However, there are many brand name drugs on the market (similar medicines) that are cheaper than generics. Other results of this study indicate a possible misunderstanding between what consumers think and what they are actually using. In the ANVISA study, $71.0 \%$ of consumers associated generics with lower price, confirming the population's good knowledge about this characteristic of generic products.

One of the generic drug policy's positive characteristics is the guaranteed comparability with the quality of the reference drug through bioequivalence and bioavailability tests, which are only mandatory for generics. The fact that $70.0 \%$ of individuals considered the quality of generics comparable to that of brand name products suggests that the government's generic policy is well implemented on this specific point. In the ANVISA study, $80.0 \%$ of consumers stated that the quality of generics was similar to that of one of the brand name drugs. However, an American study showed that between 14.0 and $53.0 \%$ of patients believed that generics were riskier than brand names, varying according to the condition being treated 8 .

While in our study $56.6 \%$ of individuals recognized at least one characteristic in the generic drug packaging that differentiates them from others, the proportion was $71.0 \%$ in the ANVISA study. A possible explanation for this difference is that the ANVISA study was conducted with consumers in pharmacies, while the current study used a household sample.

Our results indicate possible confusion between generics and similar medicines. The fact that individuals associate the word "generic" with low price may be inducing them to purchase some similar medicines, since the latter are frequently cheaper than generics, and half of the consumers could not differentiate between the two in practice. This may explain the lower prevalence of generic drug use than expected according to strategies reported for purchasing medicines.

WHO encourages the generic drug trade for both developed countries and particularly for developing ones, as a possible alternative for increasing access to medicines by poor populations 9. Unfortunately, recognition of generics was significantly worse among individuals with low schooling and low economic status,
Figure 1

Strategies for purchasing medicines among individuals who had bought any medicine on medical prescription within 15 days prior to the interview and regular purchasing habits for those who had not purchased medicines during this period. Pelotas, Brazil, 2002.

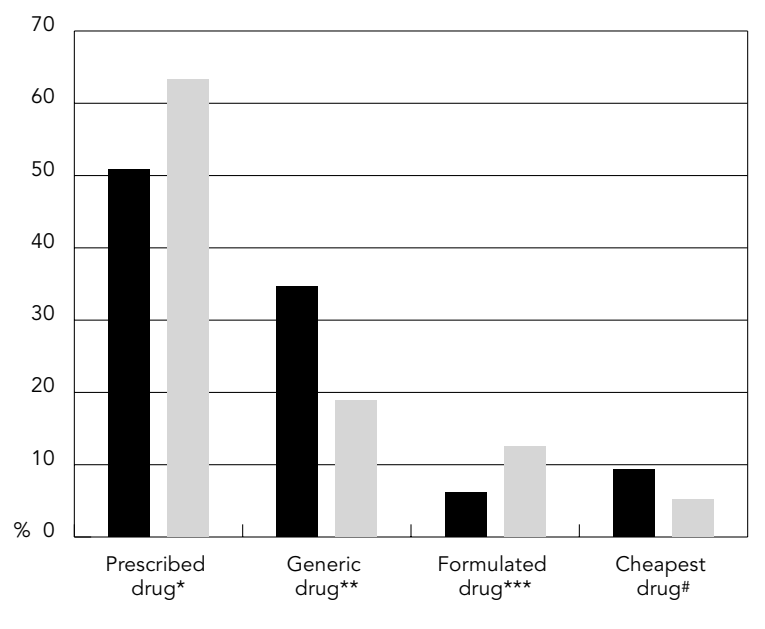

Individuals who did not buy medicines 15 days prior to the interview (habitual attitude) Individuals who bought medicines 15 days prior to the interview

* Individuals who bought (usually buy) exactly the prescribed medicine;

** Individuals who replaced (usually replace) the prescribed drug with the corresponding generic;

*** Individuals who replaced (usually replace) the prescribed drug with a formulated medicine;

\# Individuals who replaced (usually replace) the prescribed drug with a lower-priced alternative, regardless of the type.

precisely the prime target consumers of these products.

Overall prevalence of drug utilization in adults is directly related to age, with the elderly consuming more medicines 10 . The practical recognition of generics was inversely associated with age. Therefore, individuals with the highest utilization rates and thus those most likely to use generics are experiencing difficulty in recognizing these products.

The importance of information on generics was confirmed in a Spanish study 11, in which $98.8 \%$ of patients (submitted to an educational intervention on the benefits of generics) agreed to replace their prescribed medicines with generics.

Low utilization of generics (3.6\%) contrasts with high overall drug use in the same population $(65.9 \%)$ 10. This indicates high potential for expansion of the generic pharmaceuticals market in Brazil, considering that 56 therapeutic classes are supplied by generics $(60.0 \%$ of prescription needs) (IMS Health. IMS Market Prognosis Latin America. http://www.imshealth. com, accessed on 30/Nov/2003). More than 
$40.0 \%$ of the medicines marketed in Canada, Denmark, United States, and United Kingdom are generics (European Generic Medicines Association. Percent of Generic Medicines: EU Member States. http://www.egagenerics.com, accessed on 01/May/2004).

None of the independent variables was associated with generic drug use. This result is worrisome, since the elderly (with more chronic diseases and consequently more expenses with medicines) and the poor (the main potential target of the generic drug policy) should present a proportionally higher generic utilization rate than the other groups.

Table 3 shows the lower generic drug use in comparison to similar medicines in the pharmacological groups supplied by generics. The largest differences in favor of similar medicines were in analgesics, anti-inflammatory drugs, and cardiovascular drugs, exactly the pharmacological groups with the highest utilization rates.

In the practical situation of purchasing drugs on medical prescription, $63.0 \%$ of individuals reported buying exactly the product prescribed, a percentage higher than reported for their habitual drug purchases (51.0\%). While only $19.0 \%$ had chosen a generic on their last purchase, $35.0 \%$ reported habitually doing so. If all individuals who reported having purchased a generic in the previous 15 days had really done so, the percentage of generic drug use would be markedly higher.

In summary, this study shows that the most important determinants in choosing medicines are price and the medical prescription. The importance of price is evident, since individuals with higher purchasing power choose to buy brand name products while poorer individuals choose cheaper products, in this case similar medicines. Moreover, since half of the individuals who buy medicines on medical prescription report purchasing exactly the prescribed product, health professionals should be encouraged to prescribe generic drugs. Prescriptions using the generic name may help consumers to choose the types of medicines that are compatible with their incomes.

\section{Resumo}

Este estudo avaliou o conhecimento e utilização de medicamentos genéricos em uma amostra populacional de adultos de uma cidade no sul do Brasil. Os desfechos foram: proporção de genéricos sobre o total de medicamentos usados; conhecimento teórico e prático sobre medicamentos genéricos; estratégias usadas para compra de medicamentos com prescrição médica. O período recordatório para uso de medicamentos foi de 15 dias. A proporção de genéricos no total de medicamentos foi de 3,9\%. Enquanto 86,0\% sabiam que o preço dos genéricos era menor e 70,0\% que a qualidade era equivalente aos medicamentos de marca, apenas $57,0 \%$ conheciam alguma característica da embalagem que diferencia os genéricos de outros medicamentos. A maior proporção de uso de genéricos foi encontrada no grupo farmacológico dos antimicrobianos. Um medicamento de marca (com nome comercial semelhante ao genérico) foi erroneamente classificado como genérico através de fotos por 48,0\% das pessoas. Entre os indivíduos que compraram medicamentos no período de 15 dias, 18,9\% relataram comprar um genérico, mas esse resultado deve ser interpretado com cautela, pois freqüentemente a população não consegue diferenciar os genéricos dos demais medicamentos.

Farmacoepidemiologia; Custos de Medicamentos; Uso de Medicamentos; Medicamentos Genéricos; Políticas de Saúde

\section{Contributors}

A. D. Bertoldi had the original idea, coordinated the fieldwork, and led the drafting of the article. A. J. D. Barros supervised the entire data collection, analyses, and drafting. P. C. Hallal coordinated the analyses. All the authors read preliminary drafts, made suggestions, and approved the final version of the manuscript.

\section{Acknowledgments}

Coordenação de Aperfeiçoamento de Pessoal de Nível Superior (CAPES). 


\section{References}

1. Lunde PKM, Baksaas I. Epidemiology of drug utilization - basic concepts and methodology. Acta Med Scand Suppl 1988; 721:7-11.

2. Matheson I. Drug utilization in non-hospitalized newborns, infants, and children. In: Yaffe SJ, Aranda JV, editors. Pediatric pharmacology: therapeutic principles and practice. Philadelphia: WB Saunders Co.; 1992. p. 557-65.

3. Silveira FG, Osório RG, Piola SF. Os gastos das famílias com saúde. Ciênc Saúde Coletiva 2002; 7:719-31.

4. Brasil. Lei n. 9.787 de 10 de fevereiro de 1999. Diário Oficial da União 1999; 11 feb.

5. Brasil. Resolução RDC n. 32 de 9 de março de 2001. Diário Oficial da União 2001; 12 Mar.

6. Ministério da Saúde. Relação nacional de medicamentos essenciais (RENAME). Brasília: Ministério da Saúde; 2000.

7. Associação Nacional de Empresas de Pesquisa. Critério de classificação econômica Brasil. São Paulo: Associação Nacional de Empresas de Pesquisa; 1996.
8. Ganther JM, Kreling DH. Consumer perceptions of risk and required cost savings for generic prescription drugs. J Am Pharm Assoc 2000; 40:37883.

9. World Health Organization. Latin American Conference on Economic Aspects of Essential Medicines. Caracas: World Health Organization; 1992.

10. Bertoldi AD, Barros AJD, Hallal PC, Lima RC. Drug utilization in adults: prevalence and individual determinants. Rev Saúde Pública 2004; 38:228-38.

11. Vallès JA, Barreiro M, Cereza G, Ferro JJ, Martínez MJ, Cucurull E, et al. Aceptación de los fármacos genéricos en equipos de atención primaria: efecto de una intervención educativa y de los precios de referencia. Gac Sanit 2002; 16:505-10.

Submitted on 11/Aug/2004

Final version resubmitted on $04 / \mathrm{Feb} / 2005$

Approved on 07/Mar/2005 